Mkwawa Journal of Education and Development, Vol. 2, 72-93. DOI: https://doi.org/10.37759/mjed.2018.2.1.5

\title{
The Challenges Facing the Management of Immigration in Tanzania and Zambia: A case of Tunduma and Nakonde
}

\author{
David Msokwe
}

Mzumbe University-Mbeya Campus College

\begin{abstract}
Immigration is a global development issue impacting on the development trajectories of all countries. Tanzania, for instance, has seen large numbers of illegal immigrants from Burundi, Zambia, Democratic Republic of Congo (DRC) and Somalia who flee their countries because of political unrest and economic difficulties. Consequently, illegal immigration has been increasing from time to time in Tanzania. This study examined the challenges facing the management of immigration in Tanzania. Specifically, the paper used both qualitative and quantitative approaches to explore the existence and flow of illegal immigrants, causes and the challenges facing the management of illegal immigration in Tanzania and Zambia. The study found the existence of illegal immigration between Zambia and Tanzania. The patterns of flow of illegal immigrants are mainly of Zambia to Tanzania. Such pattern is caused by sharing common and related languages, colonial legacies and trade. The challenges to controlling of illegal immigration include inadequate immigration personnel and immigration control equipment, poor cooperation between coercive apparatus and the civilians and the influx of large population of immigrants. The study concludes that addressing illegal immigration requires collaboration and cooperation between Tanzania and Zambia coercive apparatus and integrating the citizens who are living along the borders.
\end{abstract}

\section{Article History}

Received 20 June 2018

Accepted 18 December 2018

\section{Keywords:}

Illegal immigration;

Immigration; Immigrants;

Tanzania; Zambia

\section{How to cite this paper:}

Msokwe, D. 2018. The Challenges Facing the Management of Immigration in Tanzania and Zambia: A case of Tunduma and Nakonde. Mkwawa Journal of Education and Development, 2(1): 72-93. DOI: https://doi.org/10.37759/mjed.2018.2.1.5 
Mkwawa Journal of Education and Development, Vol. 2, 72-93. DOI: https://doi.org/10.37759/mjed.2018.2.1.5

Challenges facing management of immigration

\section{1.o Introduction}

\subsection{Background to the study}

Migration means crossings of borders (Bean et al. 1988). People are migrating in different parts of the world to find financial and other opportunities. There are various factors that influence the trend of immigration. Some of these factors include transfer of knowledge, financial opportunities and political unrest of some countries. In all, immigration is connected to economic, social-cultural and political turmoil (Magweiga and Urassa, 2017). It has been noticed that the flow of undocumented migrants from different places such as immigrants from Mexico and other Latin American countries to United States is increasing regardless of different managing programmes that seek to inhibit such kind of movement. For example the ILO report (2008) discloses that about 2.4 million people are victims of trafficking for the purposes of forced labour around the world. Mendoza, (2004), Passel et al. (1999) and McPheters and Schlagenhauf (1981) point out in Mexico that the annual change in the number of undocumented immigrants during 1986 to 1988 was not significantly different from changes prior while between 1995 to 2000 the population increased to 0.67 million undocumented immigrants. The trend is significantly increasing from time to time due to different factors such as trade. Similarly the migration trend from Asia to other continents has been increasing since 1990 due to trade networks which was much marked in China whose population between July and December 2015 was approximated to $1,387,160,730$ people (UN, 2016).

In Africa, data shows that migration trends are such that a large number of migrants cross borders within the continent with fewer migrating from the continent to the rest of the world. For instance, between 2015 and 2017, the number of African international migrants living within the region jumped from 16 million to around 19 million whereas those moving outside the continent only increased from around 16 million to 17 million (McAuliffe \& Kitimbo, 2018). The observation by Adepoju, (2001) shows that there has been a flow of people from Tanzania and the rest of East Africa to other countries. Most of youth are transiting the East African countries particularly Tanzania to southern Africa and possibly as a detour to Europe for green pastures through trade, economy and employment opportunities. Such movements are also, as Kambidima (2010) 
Mkwawa Journal of Education and Development, Vol. 2, 72-93. DOI: https://doi.org/10.37759/mjed.2018.2.1.5

Challenges facing management of immigration

reports, determined by colonial legacies. So far, though pattern has been changing by increase and declines but a general observation indicates that the increase of emigration of Ethiopians to other countries has been larger since 2016. For example the UN (2019) projected the current net migration rate for Ethiopia in 2020 to other countries like Kenya and Tanzania to be 0.128 per 1000 population with a $36.95 \%$ decline from 2019. In 2019 it was 0.203 per 1000 population with a $26.98 \%$ decline from 2018. In 2018 it was 0.278 per 1000 population with a $29.08 \%$ decline from 2017 and in 2017 it was 0.392 per 1000 population with a 22.53\% decline from 2016. Such illegal immigration may also lead to social miseries in areas of destination.

Tanzania has been receiving immigrants from various countries including Burundi, the Democratic Republic of Congo, Rwanda and Uganda. Thus, the country has, for years, been experiencing a mixed migratory flows (IDM-Workshop, 2016). Some have been legal and others illegal migrants. Various cases drawn from Tanzania show that the trend of illegal immigration has been increasing with time and place. By referring to the Division of The United Nations Department of Economic and Social Affairs (UNDP 2009) as read in the Immigration newsletter (2010) and Annual Immigration reports (2012), illegal immigration in Tanzania has been increasing. For example, in 2006 there were 1,356 illegal immigrants, while in 2007, 2008, 2009, 2010, 2011, and in the year 2012 there were 1,798, 3,705, 4,991, 1,735, 3,502, and 4,765 respectively. These patterns of illegal immigrants in Tanzania are traced at borders. Ubwani (2012), for instance, explains that the immigration border officials in Tanzania are facing an uphill task to contain a growing wave of illegal immigrants from Ethiopia and Somalia. This leads to these immigrants to enter Tanzania illegally which might lead to socioeconomic problems.

Following such illegal immigration, various measures have been taken in both developed and developing countries to ensure there is minimal or no illegal immigration. Some of these measures include addressing potential irregular migration before the migrant arrives in the host country; enhancing border management at the external borders; detecting entry of irregular migrants onto the country's territory; monitoring, and ensuring migrant compliance with the respective conditions of their visa and other permission to stay in a country in order to avoid overstay and 
Mkwawa Journal of Education and Development, Vol. 2, 72-93. DOI: https://doi.org/10.37759/mjed.2018.2.1.5

Challenges facing management of immigration

addressing the legal situation of irregular migrants by providing ways out of irregularity (European Migration Network, 2012). Despite these efforts, the prevention of illegal immigration has not yet been achieved. Therefore, there is a need to investigate the challenges facing the management of immigration in Tanzania.

This study aimed to explore the flows of illegal immigrants between Tanzania and Zambia in order to determine the causes, and the challenges facing the management of illegal immigration in Tanzania and Zambia. Specifically, the study examined the flows of illegal immigrants between Tanzania and Zambia, explored the causes of illegal immigration between Tanzania and Zambia, and identified the challenges facing the management of illegal immigration in Tanzania. This paper contributes to existing research on illegal immigration control by adding on the body of knowledge fresh insights from Tanzania.

\subsection{Theoretical perspective}

The study is guided by permissible illegal immigration, wage differential theory and the laws of migration by Ernest George Ravenstein. Permissible illegal immigration theory by Hillman et al. (1999) propounds that in many countries, laws against immigration are not enforced. Further explanations about this theory indicate that the risk of political unrest, cultural interaction and unemployment due to policies that reduce employment opportunities for non-union workers lead to illegal immigration. In many countries laws are not enforced against visibly present illegal immigrants. The visibly present illegal immigrants also tend to be concentrated in particular sectors. Such permissible illegal immigration in an endogenous-policy model where selective sectorspecific illegality transforms illegal immigrants from non-sectorally specialised to sector-specific factors of production. This theory is useful in understanding illegal immigration dynamics at the border between Tanzania and Zambia because some factors for migration including political unrest, cultural interaction and unemployment can explain why people from other countries enter Tanzania or use it as a way to other countries (Fredriksson \& Gaston, 1999).

Wage differential theory states that if labour markets are very competitive, with identical workers and perfect mobility of labour, wages will move towards the same 
Mkwawa Journal of Education and Development, Vol. 2, 72-93. DOI: https://doi.org/10.37759/mjed.2018.2.1.5

Challenges facing management of immigration

equilibrium level. However, in reality wages can differ greatly, even for the same job. A variety of different factors account for this, including human capital difference, formal education, skills, labour market and widening pay gap. These variations force a person to migrate from one place to another. The wage differential theory by Todaro et al. (1987) and studies by Passel, Cohn, and Gonzalez-Barrera, (2012) show the flow of illegal migration between Mexico and the United States. The Mexican wage appeared to have the greatest impact and in most cases it was the only variable impacting flows of illegal Mexican migrants to the United States. Because this theory bases on economic determinants of immigration, it was useful in understanding immigration flows between Tanzania and Zambia at the Tunduma and Nakonde borders. Based on pull and push factors highlighted in this theory, the theory was useful for this study because it guided the author to identify the patterns, causes and examine the challenges facing the management of immigration in Tanzania (Passel, Cohn, and Gonzalez-Barrera, 2012).

The study was also guided by laws of migration developed by Ernest George Ravenstein in 1885 . These laws are;

i. The great body of migrants only proceed a short distance.

ii. The flow and direction is mostly to growing cities with pull factors though many migrants move step by step until they reach a town or city.

iii. The process of dispersion is the inverse of that of absorption, and exhibits similar features.

iv. Each main current of migration produces a compensating countercurrent.

v. Migrants proceeding long distances generally go by preference to one of the great centres of commerce or industry.

vi. The natives of towns are less migratory than those of the rural parts of the country 
Mkwawa Journal of Education and Development, Vol. 2, 72-93. DOI: https://doi.org/10.37759/mjed.2018.2.1.5

Challenges facing management of immigration

vii. Sexual category determines migration. The proportion of male and female migrants differs in such a way that males are more migratory than females due to economic and livelihood conditions.

The theory was useful in this study as it helped us identify the patterns of immigrants by sex. It also helped to study the flow of migrants as it is one of its suppositions that always the flow is mostly to growing cities like Tunduma in this case which is very short distance and easier for immigrants to immigrate from Nakonde to Tunduma.

\section{2.o Materials and methods}

\subsection{Description of the study area}

This study was conducted at the border of Tanzania and Zambia specifically at Tunduma and Nakonde (Figure 1) borders respectively. Tunduma is found in the southern highlands of Tanzania. It is bordered by Mbozi District in the east, Sumbawanga District in the west and Zambia in the south where Nakonde is found as it is seen in Figure 1. Tunduma is a small town in Tanzania, having a population of 97,562 (46,854 males and 50,708 females) (National Bureau of Statistics (NBS), 2013:111, 121). The area was suitable for this study due to the large influx of people from the neighbouring towns of Zambia which included Nakonde as the area within the case study. Tunduma is famous for its trade potential, farming and for livestock keeping all of which may be some of the pull factors for migration.

Nakonde sits directly across Tunduma, in Tanzania's Songwe Region, separated by the international border between Zambia and Tanzania. It is located on the Great North Road, about 990 kilometres (615 mi), north-east of Lusaka, the capital and largest city of Zambia. As of the 2010 Zambian Census, the district had a population of 118,017 people (Republic of Zambia, 2011). The flow of people from Nakonde is larger because roads are not the only challenges to Nakonde people they are also facing challenges in water sanitation, electricity and colleges which limit various socio-economic activities (Sichone, 2012). This made Nakonde a suitable area for studying cases of illegal migration. In addition to that the area was suitable for this study because it is one of the two geographical strands which experience irregular 
Mkwawa Journal of Education and Development, Vol. 2, 72-93. DOI: https://doi.org/10.37759/mjed.2018.2.1.5

Challenges facing management of immigration

migration in Tanzania. For example, the Ministerial Task Force on Irregular Migration (2008) reports that the majority of immigrants seek to use the country as a transit corridor to the southern borders with Mozambique, Malawi and Zambia en route to South Africa and beyond while others end up living in Tanzania illegally.

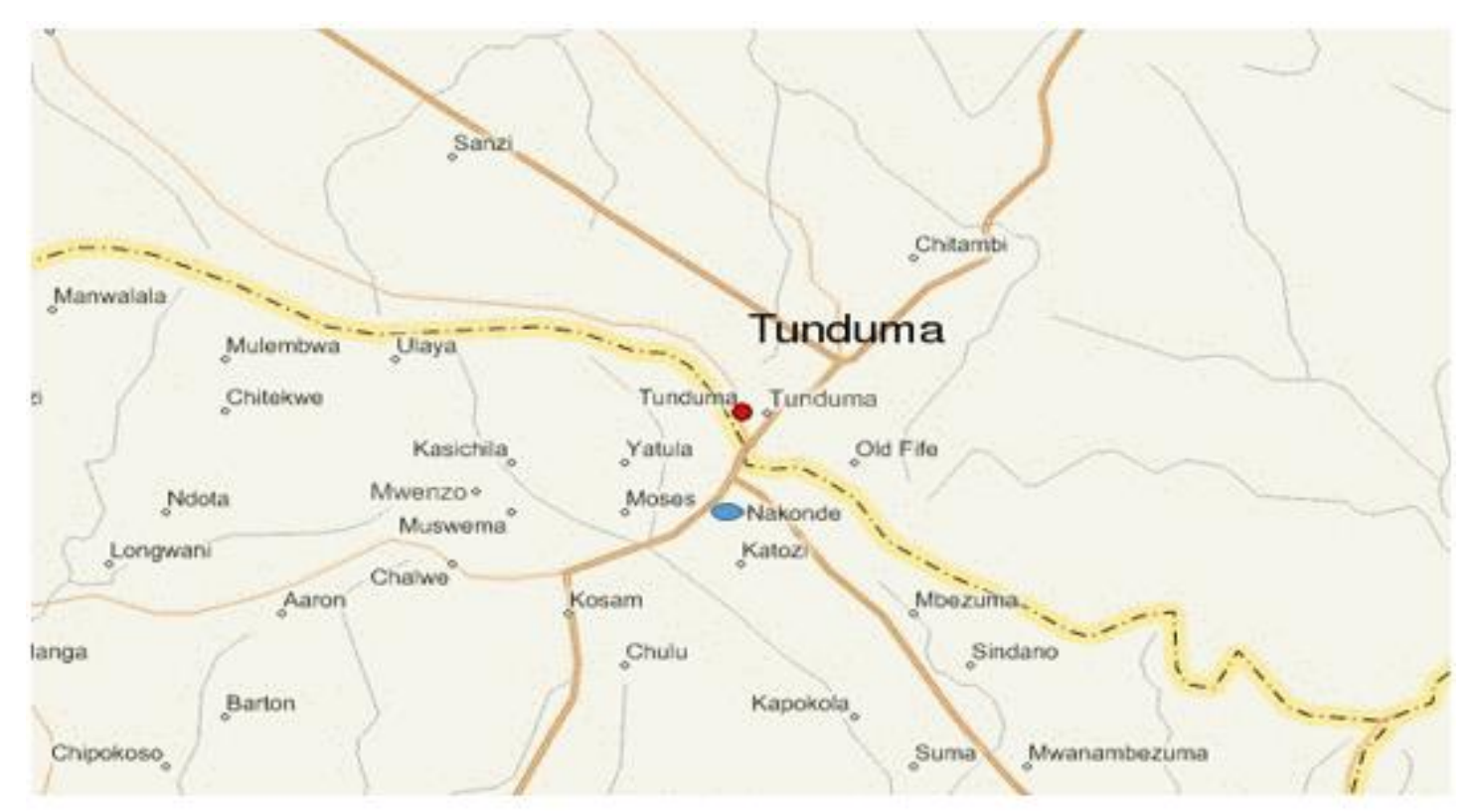

Figure 1: The map showing areas of Tunduma and Nakonde Source:

http://www.maphill.com/tanzania/mbeya/mbozi/tunduma/panoramicmaps/satellite-map/free/ Accessed on 24 ${ }^{\text {th }}$ January 2016.

\subsection{Research design}

In this study a combination of more than one approach was employed. This included the use of both qualitative and quantitative research methods in data collection and analysis. In this regard, the study used qualitative research methods in order to explain the challenges facing the management of immigration in Tanzania. Quantitative approach was used for the purpose of associating variables and examining their relationship. The survey was used because it is a well-known instrument that can be used to collect enough information. Further, the questionnaire survey was proper in this study because it is easier to administer through face-to-face conversation which allowed the researcher to capture real 
Mkwawa Journal of Education and Development, Vol. 2, 72-93. DOI: https://doi.org/10.37759/mjed.2018.2.1.5

Challenges facing management of immigration

feelings of respondents from what they were explaining and collect accurate data from the real environment rather than using mailed questionnaires or phone calls.

\subsection{Sample size determination}

A total of eighty-five (85) respondents were involved in this study. This included 60 survey participants and 25 interview and focus group discussion participants. A fair balance between the participants from Tanzania and Zambia was maintained. The participants were randomly selected at the border in order to avoid biasness. On indepth interviews, three immigration officers and ten street leaders were involved as key informants. To make the paper richer, the two focus group discussions with six participants each were also included. Thus, eighty-five respondents were involved in this study.

Table 1: Sample Size of the study

\begin{tabular}{|l|l|c|c|}
\hline \multicolumn{2}{|l|}{ Characteristics of the respondents } & $\begin{array}{l}\text { No. of } \\
\text { Respondents }\end{array}$ & \% \\
\hline \multirow{3}{*}{ Sex } & Male & 50 & 58.8 \\
\cline { 2 - 4 } & Female & 35 & 41.2 \\
\hline \multirow{5}{*}{ Education level } & Primary & 26 & 30.6 \\
\cline { 2 - 4 } & Secondary & 32 & 37.6 \\
\cline { 2 - 4 } & College & 23 & 27.1 \\
\cline { 2 - 4 } & University & 4 & 4.7 \\
\hline Nationality & Tanzanian & 47 & $55 \cdot 3$ \\
\cline { 2 - 4 } & Zambian & 38 & 44.7 \\
\hline Age (years) & $\mathbf{1 8 - 3 5}$ & $\mathbf{2 7}$ & 31.8 \\
\cline { 2 - 4 } & 36-53 & 45 & $\mathbf{5 2 . 9}$ \\
\cline { 2 - 4 } & 54 or above & $\mathbf{1 3}$ & $\mathbf{1 0 0}$ \\
\hline Total & & $\mathbf{8 5}$ & \\
\hline
\end{tabular}

Source: Field Survey, 2016

\subsection{Data collection tools}

Three tools were used during data collection. These are in-depth interviews, focus group discussion and questionnaires. The details in brief for these tools are presented hereunder. 
Mkwawa Journal of Education and Development, Vol. 2, 72-93. DOI: https://doi.org/10.37759/mjed.2018.2.1.5

Challenges facing management of immigration

In-depth interview was used to gather information from respondents on patterns, causes and the challenges facing the management of immigration in Tanzania and Zambia. A total of thirteen face to face interviews were done (ten street leaders and three officials from Zambia and Tanzania Immigration Post Offices). Each interview lasted between thirty to sixty minutes. Interviews were conducted in any of the three commonly spoken languages, namely, English, Swahili and Kiwemba. The interview material was later translated into English Language. Interviews allowed the researcher to probe for particular responses, clarifications and confirmations of information from the respondents.

Focus group discussion (FGD) was used to collect the data from villagers and other officials such as street leaders. Two groups based on different demographic characteristics of six participants each, making a total of twelve individuals, were formed during focus group discussion. In terms of location, respondents were picked from different parts of Tunduma and Nakonde. A checklist of what was expected to be discussed was prepared well in advance to make sure that all the intended issues are well covered in between 60 and 90 minutes. During focus group discussions, participants were asked questions designed to draw their attention and response on topics related to the study. Respondents were allowed to answer in their own words in either English, Swahili or Kiwemba languages rather than having to choose from predetermined options as it is the case with questionnaires. The responses from respondents who could not speak Swahili or English were translated by the researcher and one of key informants from Zambia who was hired as short time research assistant during this study. These responses were recorded instantly by a tape recorder and later translated in written form. The information from the groups helped to supplement data collected using interviews and questionnaires, which enhanced the possibilities for triangulation.

Lastly, 60 questionnaires were administered in order to collect quantitative data on immigration dynamics at the Tanzania-Zambia border. The time limit for each questionnaire was 30 to 45 minutes. This made it possible to collect adequate information and opinions from the respondents within a short period of time. To 
Mkwawa Journal of Education and Development, Vol. 2, 72-93. DOI: https://doi.org/10.37759/mjed.2018.2.1.5

Challenges facing management of immigration

enrich the research data, both open and closed questionnaires were included during data collection.

\subsection{Data analysis}

All the information from the questionnaires was entered into Statistical Package for Social Sciences (SPSS Version 16) and Microsoft excel. These programmes were used to generate descriptive statistics, graphs, tables, figures and charts. The interpretation of the descriptive statistics made it possible to make appropriate inferences in terms of determining the influences and relationship between variables. The qualitative data were analysed into themes and concepts by preparing and organising the field data, printing the recorded notes, documents, or other materials, reviewing them by creating initial codes which were combined into themes that brought meaningful and conclusive remarks. This allowed the identification of relationship of variables, themes and concepts.

\subsection{Validity and reliability}

In order to ascertain the validity of instruments, opinions were extracted from different respondents. The content and format of the questionnaires, interviews and focus group discussion organisation were approved by reading them several times by researcher and critics from other researchers. Also to ascertain the validity and reliability of the research instruments, a pilot study was conducted in some parts of the study area and at immigration offices of Tunduma.

\section{3.o Results and discussion}

\subsection{Demographic characteristics}

Demographic characteristics are socioeconomic variables of a population expressed statistically. These include age, sex, education level, income level, marital status, occupation, religion, birth rate, death rate, average size of a family, average age at marriage. For this paper demographic variables involved were sex, education level and nationality as was shown in Table 1 above.

\subsection{The existence of illegal immigration}


Mkwawa Journal of Education and Development, Vol. 2, 72-93. DOI: https://doi.org/10.37759/mjed.2018.2.1.5

Challenges facing management of immigration

The paper investigated on the existence of illegal immigration. To get the answers for this, respondents were asked whether or not illegal immigration exists. Various responses were provided as presented in Table 2.

Table 2: The existence of illegal immigration in Tanzania

\begin{tabular}{|l|c|c|c|c|}
\hline \multicolumn{5}{|l|}{ Is there illegal immigration? } \\
\hline Responses & Frequency & Percent & Valid Percent & $\begin{array}{c}\text { Cumulative } \\
\text { Percent }\end{array}$ \\
\hline Yes & 35 & 58.5 & 58.5 & 58.5 \\
\hline No & 20 & 33.0 & 33.0 & 91.5 \\
\hline Not sure & 5 & 8.5 & 8.5 & 100.0 \\
\hline Total & $\mathbf{6 0}$ & $\mathbf{1 0 0 . 0}$ & $\mathbf{1 0 0 . 0}$ & \\
\hline
\end{tabular}

Source: Field survey, 2016

The data in Table 2 indicates that the majority of respondents $(58.5 \%)$ were of the opinion that illegal immigration exists in Tanzania; 33\% did not agree and 8.5\% were not sure about its existence. In one of the FGDs, one participant was of the following opinion on the existence of illegal immigration:

In this small town we have had a great deal of interaction due to the fact that geographical boundaries are closer, there are Zambian settlers and also migrants in Tanzania, who do not have official immigration permits (FGD Participant/Mwaka/January, 2016).

\subsection{The flows and causes of illegal immigration in Tanzania and Zambia}

The respondents were asked a question on whether many illegal immigrants flowed from Zambia to Tanzania. Based on "YES, NO and NOT SURE" responses, it was found that there has been a flow of illegal immigrants from Zambia to Tanzania because of socio-economic benefits. The statistical data obtained from the field is presented by the use of pie chart in Figure 2 below. 
Mkwawa Journal of Education and Development, Vol. 2, 72-93. DOI: https://doi.org/10.37759/mjed.2018.2.1.5

Challenges facing management of immigration

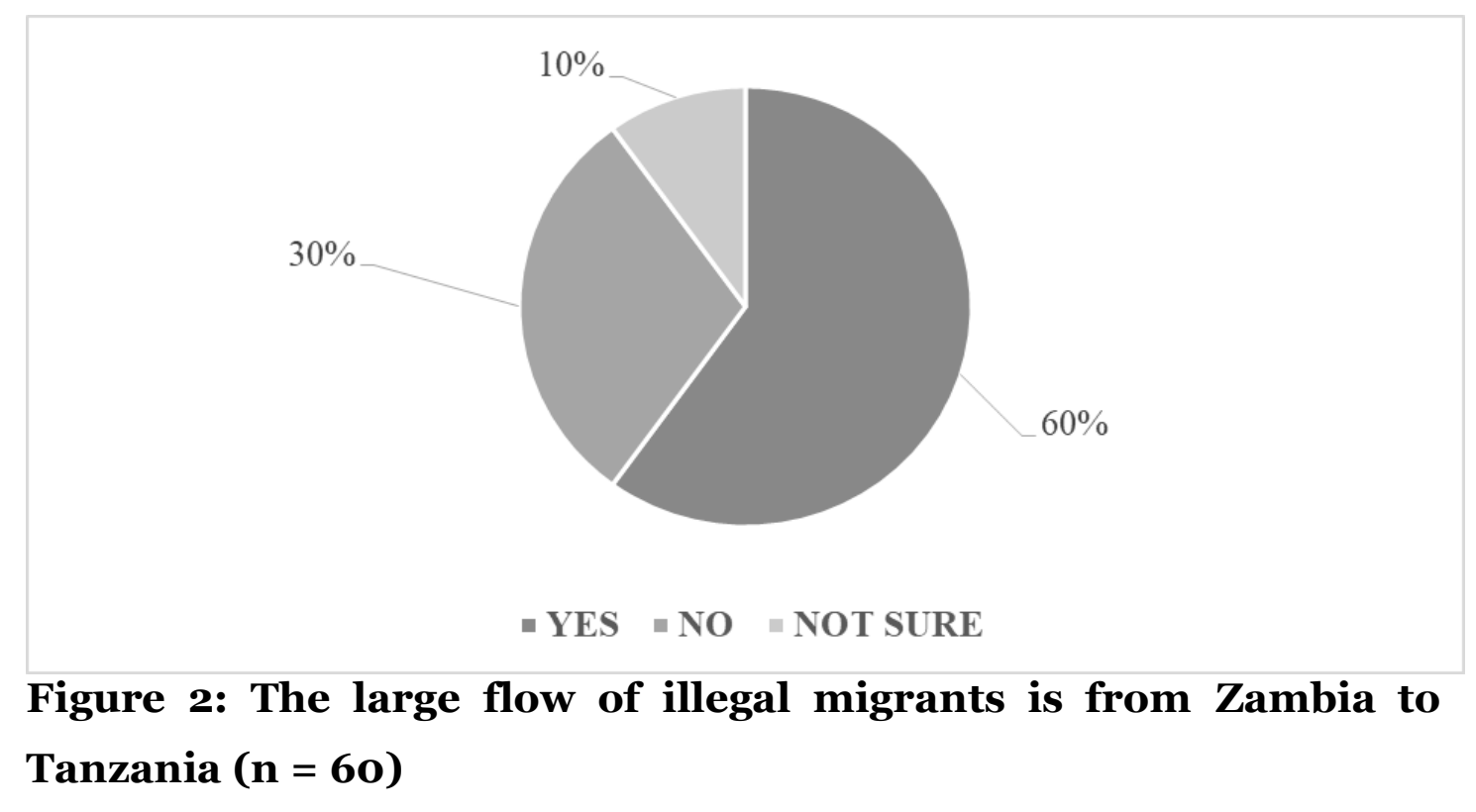

Source: Field Survey, 2016

As shown in Figure 2, 60\% of the total respondents were of the view that large flows of migrants is from Zambia to Tanzania. On the other hand, 30\% did not agree and 10\% were not sure. Though the results indicate the presence of two patterns of flow, majority are flowing from Zambia to Tanzania's Tunduma town centre. This is because of Tunduma being more economically potential due to its vibrant trade opportunities. Findings from in-depth interviews and FGDs indicated that illegal immigration in Tanzania is of several patterns that is Zambia to Tanzania and Tanzania to Zambia. It was found that majority of immigrants flow from Zambia to Tanzania, and among these many of them were males.

These patterns and the existence of illegal immigration are caused by pull and push factors. These involved languages and colonial regimes and legacies. Africa has been one, save diversity in languages, but all in all most Africans would understand each other. For this reason, one can stay in any neighbouring country without facing any language barrier. For example, it was learned that Kiwemba and Kinyamwanga languages are likely to be similar in the sense that they facilitate communication between the two neighbouring countries and thus interaction between Zambians and Tanzanians becomes easier. This increases the interaction in such a way that it is easy for a Zambian to immigrate to Tanzania for residing which then reduces the effectiveness of control measures of illegal immigration. For 
Mkwawa Journal of Education and Development, Vol. 2, 72-93. DOI: https://doi.org/10.37759/mjed.2018.2.1.5

Challenges facing management of immigration

instance, in an interview with one of the key informants at Nakonde, it was revealed that:-

Tanzania has been just like my home because their language is similar to kiBemba in such a way that interaction is simple and one cannot notice easily if I am a Zambian. Even wearing style is slightly common as inherited from our forefathers (Key Informant/Nakonde/January, 2016).

Another reason for illegal immigration was due to geographical reason since there is short distance between Zambia and Tanzania as also argued in the laws of migration by Ernst George Ravenstein in 1885. It was found in one of the FGDs that travelling from Tanzania to Zambia or Zambia to Tanzania does not cost much money as compared to if someone decides to go to Kenya hence it is for that reason that makes many people to immigrate to Tanzania. These key informants as well as direct observation revealed that there are many shops owned by Tanzanians in Lusaka, Kitwe, Matumbo, Kapili, Ndola, Nakonde and Kasumbalesa. Similarly there are many traders from Zambia whose shops are found in Tunduma. One participant in one FGD reported the same thing that:-

It has been just like one family between Tanzanians and Zambians. For example, one of my neighbour in my street has a shop in Tanzania and is just walking when going to his shop daily. This intensifies illegal immigration because some decide to change their residences because of this neighbourhood (FGD Participant/Nakonde/January, 2016).

Through FGDs it was found that immigrants are breaching laws of legal immigration due to complications for getting visa or immigration permits. Though social cultural factors also add to this kind of migration as it is also argued in other scholars' and organisations' findings like that of Hillman et al. (1999) that illegal immigration occurs because of breaching immigration laws, marriage and instability in neighbouring countries. This study, however, did not get enough evidence related to instability as among the factors for illegal immigration. Other reasons were trading networks, for example some respondents reported that in Zambia the accumulation of money is easier but its value was down compared to Tanzania that is why there are many Zambians migrating to Tanzania from some parts of Zambia like Kitwe, Matumbo, Kapili, Ndola and Nakonde because the value of Tshs was higher than Kwacha and searching of land in Tanzania was also another reason for entering the country. 
Mkwawa Journal of Education and Development, Vol. 2, 72-93. DOI: https://doi.org/10.37759/mjed.2018.2.1.5

Challenges facing management of immigration

It was further learned that on the way to achieve independence in Zambia, Dr. Keneth Kaunda adopted an ideology of African socialism, close to that of Julius Nyerere in Tanzania. Economic policies focused on central planning and nationalisation, and a system of one party rule was put in place (Kambidima, 2010). Together, these factors are thought to have created good relations between the two countries, a factor that can explain the existence of illegal immigration today.

\subsection{The trend of immigration among males and females}

The study examined the trend of immigration among males and females. When asked whether or not males are more migratory than females, respondents had different responses. A variation of responses based on "yes", "no" and "not sure" was provided and these are shown in Figure 3 hereunder.

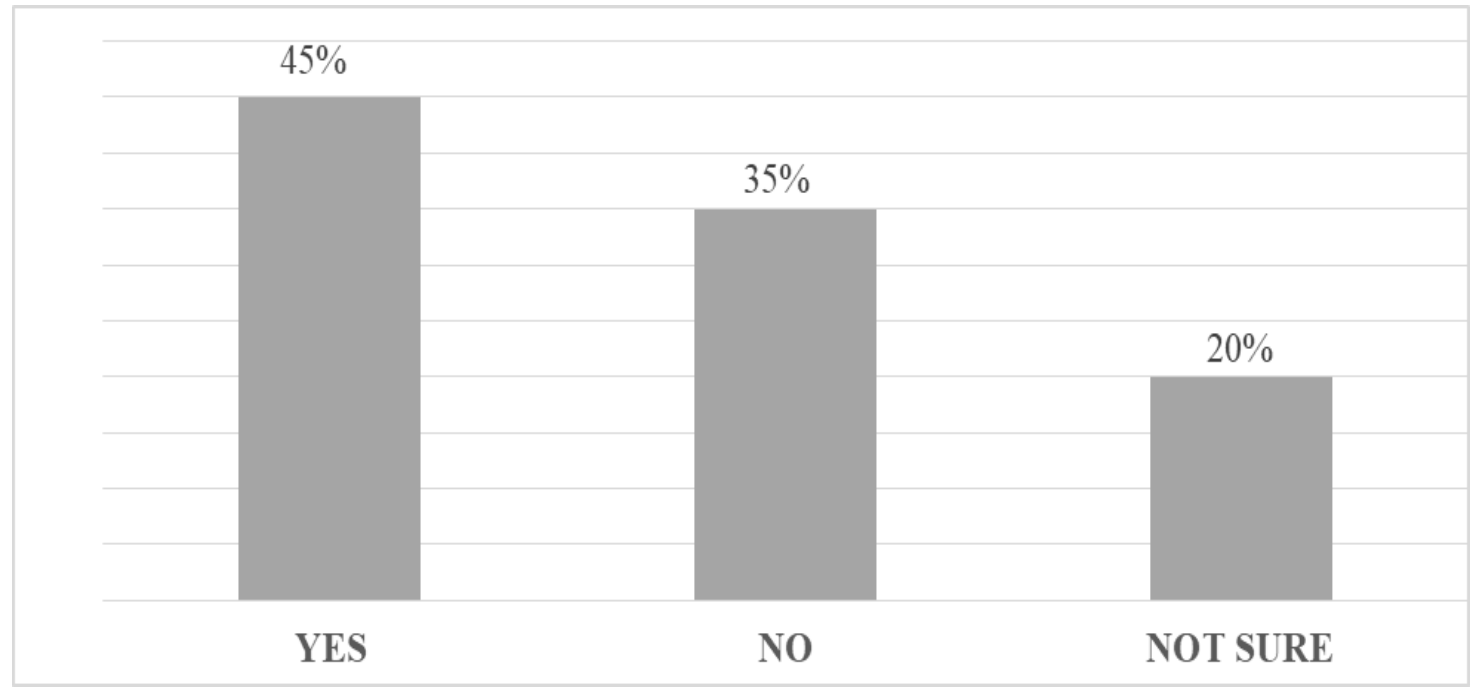

Figure 3: Are males more migratory than females? $(n=60)$

Source: Field survey, 2016

The results in Figure 3 show that $45 \%$ of the respondents reported that males are more migratory than females as compared to $35 \%$ who disagreed and $20 \%$ who were not sure. Similar cases were observed by UN (2016) in Asia, that the number of male migrants grew significantly more than the number of female migrants. Accordingly, the stock of male migrants in Asia grew by 62 per cent, from 27 million in 2000 to 44 million in 2015 whereas the percentage of female migrants fell from 45.6 per cent in 2000 to 42 per cent in 2015 (UN, 2016). 
Mkwawa Journal of Education and Development, Vol. 2, 72-93. DOI: https://doi.org/10.37759/mjed.2018.2.1.5

Challenges facing management of immigration

Table 3: The trend of immigration among males and females by sex

\begin{tabular}{|l|c|c|c|c|}
\hline \multirow{2}{*}{ Sex } & \multicolumn{2}{|c|}{ Are males more migratory than females? } & \multirow{2}{*}{ Total } \\
\cline { 2 - 4 } & Yes & No & Not sure & \\
\hline Male & $16(26.7 \%)$ & $11(18.3 \%)$ & $8(13.3 \%)$ & \multirow{3}{*}{$\mathbf{3 5}(58.3 \%)$} \\
\hline Female & $11(18.3 \%)$ & $10(16.7 \%)$ & $4(6.7 \%)$ & $\mathbf{2 5 ( 4 1 . 7 \% )}$ \\
\hline Total & $\mathbf{2 7}(45.0 \%)$ & $\mathbf{2 1}(35.0 \%)$ & $\mathbf{1 2 ( 2 0 . 0 \% )}$ & $\mathbf{6 0 ( 1 0 0 . 0 \% )}$ \\
\hline
\end{tabular}

$\mathrm{X}^{2}=6.59, \mathrm{p}$-value $=0.719 \&$ degree of freedom $=2$

Source: Field Survey, 2016

A further analysis was done through sex cross tabulation, whereby results showed males to be more migratory. In the context of immigration by sex, males were regarded to be more migratory due to factors of trade whereas females were considered to be more migratory because of social factors like marriage and lineages. In the data indicated in Table 3, about $27 \%$ of males agreed that males are more migratory than females whereas $18.3 \%$ disagreed and $13.3 \%$ were not sure on the same thing. About $18 \%$ of females agreed that males are more migratory than females while $16.7 \%$ disagreed and $7 \%$ were not sure on the same thing. The patterns of reporting indicates that majority of males and females agreed that males are more migratory than their counterpart females. These results were statistically insignificant since the chi-square test is 5.243, p-value is 0.073 and the degree of freedom is two. This signifies that the pattern of immigration between males and females can change due to changes of economic patterns and other socio-cultural factors.

The cross tabulation of sex, and the pattern of flow from Zambia to Tanzania had large number of YES responses. This was due to reasons such as Tanzania being the centre for foreign goods importation via harbours relative to Zambia which is landlocked; a good place for settlement; and perceived availability of employment opportunities. Majority of those who reported NO meaning that the flow is not much from Zambia to Tanzania rather it is from Tanzania to Zambia were traders who in most cases take their commodities to Zambia in search for market. These findings are in line with McPheters and Schlagenhauf (1981) who reported that the 
Mkwawa Journal of Education and Development, Vol. 2, 72-93. DOI: https://doi.org/10.37759/mjed.2018.2.1.5

Challenges facing management of immigration

Mexican males migrate more in order to get employment opportunities. In an interview with one of key informants at the Nakonde border, it was revealed that:

This dominant flow (Zambia to Tanzania) was reported to be dominant due to historical reasons; previously some parts of Tanzania like Vwawa (in Mbozi District) were parts of Zambia when it was known as Southern Rhodesia. However, such interaction has been causing various socioeconomic miseries including lack of freedom of expression due to variation in languages between Tanzanians and Zambians; environmental pollution; family separation; loss of citizenship; land conflicts especially in some places like Vwawa, Mponela Village, Ihanda, Mpakani Tunduma etc.; working competitions; limitation of movement due to some immigrants coming with bad habits like robbery; increasing price of food, water, education, etc... (Key Informant/NakondeTunduma/January, 2016).

\subsection{Challenges facing the management of illegal immigration}

The exploration of the challenges facing the management of illegal immigration was done in this study. Various responses from respondents were provided. These responses are statistically presented in Figure 4.

Is there any challenge facing the management of illegal immigration?

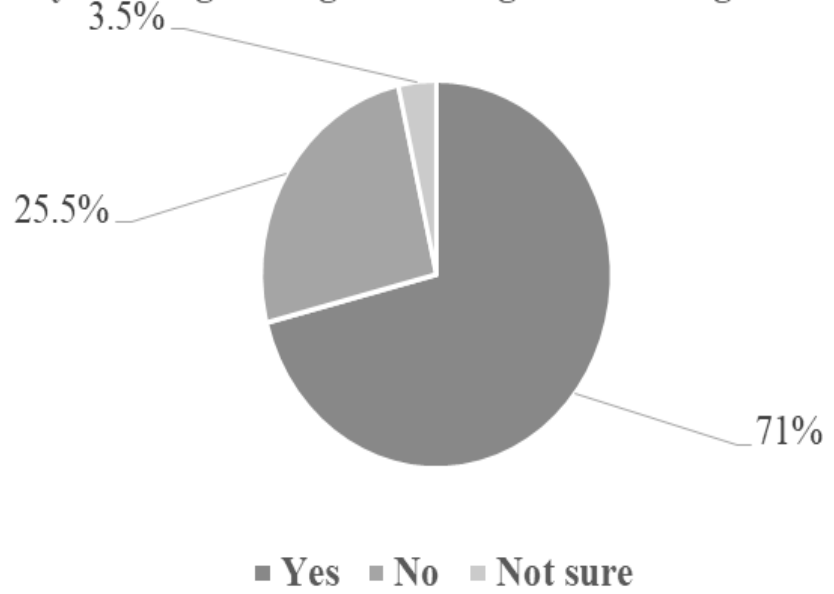

Figure 4: Presence of challenges facing the management of illegal immigration $(n=60)$

Source: Field Survey, 2016

The results from open ended questionnaires show that the challenges such as large size of the border with shortage of immigration posts; cultural similarities, language in particular; modernisation, the domination of materialism approach and 
Mkwawa Journal of Education and Development, Vol. 2, 72-93. DOI: https://doi.org/10.37759/mjed.2018.2.1.5

Challenges facing management of immigration

development of science; similar colonial regimes and technology which allowed large interaction were identified as challenges facing the management of illegal immigration. Figure 4 indicates that $71 \%$ of the respondents agreed that there are challenges that face the management of illegal immigration in Tanzania whereas 25.5\% disagreed and 3.5\% were not sure. Since the proportion of those who agreed is larger compared to other proportions, it can be concluded that there are challenges facing illegal immigration management in the studied area. Furthermore, the responses over the presence of the challenges facing the management of illegal immigration was cross tabulated by levels of education and the results are presented in Table 4.

Table 4: Presence of the challenges facing the management of illegal immigration

\begin{tabular}{|c|c|c|c|c|}
\hline \multicolumn{5}{|c|}{$\begin{array}{l}\text { Are there any challenges facing the management of illegal } \\
\text { immigration? }\end{array}$} \\
\hline \multirow{2}{*}{$\begin{array}{l}\text { Education } \\
\text { level }\end{array}$} & \multicolumn{3}{|c|}{ Responses } & \multirow[b]{2}{*}{ Total } \\
\hline & Yes & No & Not sure & \\
\hline Primary & $14(23.5 \%)$ & $3(6.0 \%)$ & $1(0.5 \%)$ & $18(30.0 \%)$ \\
\hline Secondary & $12(20.5 \%)$ & $9(16.0 \%)$ & $2(2.5 \%)$ & $23(39.0 \%)$ \\
\hline College & $13(22.5 \%)$ & $2(3.5 \%)$ & $1(0.5 \%)$ & $16(26.5 \%)$ \\
\hline University & $3(4.5 \%)$ & $0(0.0 \%)$ & $\mathrm{O}(0.0 \%)$ & $3(4.5 \%)$ \\
\hline Total & 42(71.0\%) & \begin{tabular}{|l|}
$14(25.5 \%)$ \\
\end{tabular} & $4(3.5 \%)$ & 60(100.0\%) \\
\hline
\end{tabular}

Source: Field Survey, 2016

The examination of the presence of challenges facing the management of illegal immigration needs an in-depth analysis in such a way it is suitable to study according to the levels of education. In this regard Table 4 indicates the responses over the presence of challenges facing the management of illegal immigration in Tanzania. About 24\% of the respondents with primary education agreed over the presence of the challenges facing the management of illegal immigration in Tanzania whereas $6 \%$ disagreed and $0.5 \%$ were not sure about the same thing. $25.5 \%$ of the respondents with secondary education agreed whereas $16 \%$ disagreed 
Mkwawa Journal of Education and Development, Vol. 2, 72-93. DOI: https://doi.org/10.37759/mjed.2018.2.1.5

Challenges facing management of immigration

and $2.5 \%$ were not sure on the same thing. About $23 \%$ of the respondents with college level of education agreed whereas 3.5\% disagreed and $0.5 \%$ were not sure whether or not there are challenges facing the management of illegal immigration in Tanzania. Finally, $4.5 \%$ of the respondents with university level of education agreed on the same thing. These results are statistically significant $\left(\chi^{2}=23.391 \mathrm{P}-\right.$ value $=0.001$, degree of freedom $=6$ ). Thus, it is obvious that the management of illegal immigration faces challenges. Based on challenges facing the management of illegal immigration, one key respondent from Nakonde and Tunduma train station reported that:

These challenges exist due to various reasons such as few immigration officers, shortage of remote sensing and geophysical equipment for patrolling between and across borders as well as poor cooperation between coercive apparatus and the civilians in reporting such kind of immigration out of the recognised border(s) (Key Informant/NakondeTunduma/January, 2016).

More so, the FGDs also revealed more challenges facing the management of illegal immigration in Tanzania. One of these challenges was large population of immigrants and large size of the border with few post offices and officers and poor coordination between civilians and street leaders (police, migration officers, civilians). Also difference in level of seriousness with border control between the two countries: in Zambia immigration authority manages to control easily due to the small size of the country compared to Tanzania where it is reported that foreigners are not bothered in some areas where there are no immigration posts and these were associated to the issue of poor governance especially street leaders at local government authority, corruption among street leaders and the presence of few immigration check points. On the aspect of poor coordination between civilians and their street leaders, one of the government officials had this to say:

There has been lack of networks, such problem has led to poor information flow from the citizens to the immigration authority. Such problem probably leads to different observation between the authority and civilians that the authority can have the data about illegal immigration whose trend is decreasing while civilians may have knowledge about illegal immigration which show the increase in illegal immigrants. Usually civilians will report the presence of illegal 
Mkwawa Journal of Education and Development, Vol. 2, 72-93. DOI: https://doi.org/10.37759/mjed.2018.2.1.5

Challenges facing management of immigration

immigrant if it happens that there is a criminal offence case like land dispossession, theft and fighting. So far, there have been some immigrants who have stayed in the country for more than eight years of which it becomes difficult to notice if he/she is illegal immigrant because of being very familiar to the national and vernacular languages such as Swahili, Nyiha and Nyamwanga and due to lack of BVRs [Biometric Voter Registration] and National IDs [identities] among some Tanzanians (Key Informant/Mbozi immigration office/January, 2016).

To this end, one can then say that immigration which takes place in Tanzania along Tunduma border is mainly caused by factors which do not make an immigrant to move by force as it is in Kigoma where immigrants entre Tanzania not because of their will but wars in Burundi, Rwanda and Democratic Republic of Congo.

So far, the statistical information indicate significance in some tables while insignificance in others. This means that the pattern of immigration changes with time with increasing and decreasing pace with time and place that is why the pvalues within the tables are not consistent. For example, according to the reports and records from the Immigration Department following the Ministerial Task Force on Irregular Migration results (2008) as of 31st August 2007 there were some 41,262 officially identified irregular migrants in Kagera region. Of these, 18,510 left the country but some 22,752 remained in the region. Around the same time, Kigoma and Rukwa had 18,508 and 14,443 officially known illegal immigrants respectively. Such fluctuating trend is also reported by data from Division of the United Nations Department of economic and Social Affairs (UNDP, 2009) in the Immigration newsletter (2010) and the Annual Immigration reports (2012).

In all, taking measures to address the challenges for illegal immigration is important because legal immigration is one of the sources of national income. For example, the ILO Vietnam forum (2008) indicated that the immigration under legal basis is a lucrative business which generates about USD 3.2 billion in annual profit. Measures are also important due to rules and regulations which are set in the country. For example, according to the Immigration Act no. 7 of 1995 of Tanzania, unlawful immigration is a criminal offence punishable by jail sentence or monetary penalty or both of them and subsequently deported to where he/she came. 
Mkwawa Journal of Education and Development, Vol. 2, 72-93. DOI: https://doi.org/10.37759/mjed.2018.2.1.5

Challenges facing management of immigration

\section{4.o Conclusion}

This paper sought to examine the challenges facing the management of illegal immigration in Tanzania and Zambia. It was qualitative and quantitative research. 85 respondents participated in the study. Primary and secondary methods were applied in the process of data collection whereas qualitative and quantitative methods were applied in the process of analysis. The findings show that the flow of migrants is mainly Zambia to Tanzania and it proved the existence of illegal immigration in Tanzania due to languages, colonial regimes and legacies, trade and many others. Thus, following a large magnitude of respondents who were of the view that illegal immigration existed, one can argue that illegal immigration exists at Tanzania's borders as reported by people living at the borders.

This study has revealed various challenges facing the management of illegal immigration. These challenges are large size of the border with shortage of immigration posts; poor coordination between Tanzanians and their street leaders; cultural similarities, language in particular; modernisation; the domination of materialism approach and development of science; similar colonial regimes and technology. But some of these challenges such as cultural interaction and large size of the Tanzania country border with the shortage of immigration check points can be solved by the country if it increases the efforts. Therefore it can be concluded that the management of illegal immigration in Tanzania is within the capacity of the immigration authorities with more participation of local leaders to support management initiatives.

It is recommended that the respective authorities should work effectively by increasing the immigration officers and posts (establishment of additional Official Entry Points), illegal immigration control in the context of international and national cooperation with local leaders, and coercive apparatus to work twenty four hours in cooperation with local or street leaders (to ensure there is use of participatory security approach). Such coordination can help to minimise the gap caused by limited number of immigration officers. Capacity building is also recommended especially when dealing with the challenge of modernisation and the application of remote sensing technology as indicated in the findings. In building 
Mkwawa Journal of Education and Development, Vol. 2, 72-93. DOI: https://doi.org/10.37759/mjed.2018.2.1.5

Challenges facing management of immigration

capacity, training of Immigration and other Border Officials is important for law enforcement officials in order to enable them to profile irregular migrants and channel them to appropriate response mechanisms, recognise illegal immigrants and be able to handle them in accordance with the law and standard operating procedures for controlling illegal immigration to be developed.

\section{References}

Adepoju, A. (2001). Regional Organisations and Intra-Regional Migration in SubSaharan Africa. International Migration, 39(6), pp. 43-6o.

Bean, F. D., Lowell, B.L. and Taylor, L.J. (1988). Undocumented Mexican Immigrants and the Earnings of Other Workers in the United States. Demography, 25(1), pp. 35-52.

European Migration Network (2012). Practical Measures to Reduce Irregular Migration. Available online at: https://ec.europa.eu/homeaffairs/sites/homeaffairs/files/what-we-

do/networks/european_migration_network/reports/docs/emn-studies/irregularmigration/ooa emn synthesis report irregular migration october 2012 en.pd f

Fredriksson, P. G \& Gaston, N. (1999). The greening of trade unions and the demand for eco-taxes. European Journal of Political Economy, 15(4), pp. 663-686.

Hillman, A. L., Weiss A. (1999). A theory of permissible illegal immigration, London: Barllan University.

IDM-Workshop. (2016). Innovative Approaches to Addressing Migration Issues in Tanzania. Dar es Salaam: Ministry of Home Affairs.

Immigration Act no. 7 of Tanzania of 1995.

Immigration Newsletter no. 13 of January-April 2010.

Kambidima. W. (2010) Deriving Ethno-geographical Clusters for Comparing Ethnic Differentials in Zambia. World Cultures Journal, 17(2), pp.1-31.

Magweiga, R. S and Urassa, J. K. (2017). Factors contributing to irregular migration: A case of Kasulu District, Tanzania. Journal of African Studies and Development, 9(5), pp.67-81.

McAuliffe, M. and Kitimbo, A. (2018). African migration: what the numbers really tell us. World Economic Forum (WEF). Accessed from: https://www.weforum.org/agenda/2018/06/heres-the-truth-about-africanmigration/ 
Mkwawa Journal of Education and Development, Vol. 2, 72-93. DOI: https://doi.org/10.37759/mjed.2018.2.1.5

Challenges facing management of immigration

McPheters, L. R. and Schlagenhauf, D. E. (1981) Macroeconomic Determinants of the Flow of Undocumented Aliens in North America. Growth and Change: $A$ Journal of Urban and Regional Policy, 12(1), pp. 2-8.

Mendoza, C. (2004). Transnational circuits and spaces in migration between Mexico and the United States: contributions from a survey of fluids. Migrations Internationals, 2, pp. 83-109.

NBS. (2013). 2012 Population and Housing Census: Population Distribution by Administrative Areas. Dar es Salaam and Zanzibar: NBS and Office of Chief Government Statistician President's Office, Finance, Economy and Development Planning.

Passel, J. S, Cohn, D. and Gonzalez-Barrera, A. (2012). A Net Migration from Mexico Falls to Zero-and Perhaps Less. Pew Research Centre, Hispanic Trends.

Passel, J. S. (1999). 'Undocumented Immigration to the United States: Numbers, Trends, and Characteristics.' In Haines, D.W. and Rosenblum, K.E. (eds.), Illegal Immigration in America. Westport, CT: Greenwood Press, pp. 27-111.

Republic of Zambia. (2011). 2010 Census of Population and Housing: Preliminary Figures. Lusaka: Central Statistical Office

Sichone, M. (2012). "Why is there no development in Nakonde?" Zambiawatchdog.com. Retrieved 3 October 2018.

The Ministerial Task Force on Irregular Migration. (2008). Report on the Situation of Irregular Migration in Tanzania. Dar es Salaam: Ministry of Home Affairs.

Todaro, M. P., Maruszko, L. (1987). Illegal immigration and U.S. immigration Reform: A conceptual framework. Population and Development Review, 13, pp. 101-114.

Ubwani, Z. (2012). Tanzania's stern warning to illegal migrants in Kilimanjaro, Tanzania.

UN. (2016). International Migration Report. New York: Department of Economic and Social Affairs.

UN. (2019). Revision of World Population Prospects. Department of Economic and Social Affairs of the United Nations Secretariat.

United Republic of Tanzania. (2012). Annual Immigration Reports. Dar es Salaam. 